\title{
THE CONTINENTAL AND COMMON-LAW CONCEPTIONS OF CRIMINALISTICS
}

\author{
Csaba Fenyvesi*
}

The study examines the main difference, definition of continental and common law aspects of criminalistics, (forensic science) as factscience from the "father of criminalistics" Hans Gross to updating, modern, international (American, British, French, German, Hungarian) concepts. So, it sounds about specialties of criminal investigation, crime-solving techniques, criminal tactics, technology, criminal methodology and generally about parts of forensic sciences.

INTRODUCTION 46

I. DEFINITIONS OF CRIMINALISTICS IN EUROPE ......................................4 47

II. DEFINITIONS OF CRIMINALISTICS IN ANGLO-SAXON COUNTRIES .............50

III. COMPARING OF THE TWO SYSTEMS OF CRIMINALISTICS .......................54

CONCLUSION ........................................................................... 57

\section{INTRODUCTION}

At the beginning of the 21 st Century, it is timely and appropriate to provide a conceptual analysis of what (modern) heoretical and practical criminalists have been dealing with in the past 120-170 years and of the tendencies that may be perceived in today's conceptions of criminalistics.

Academic literature seems to be uniform in its summary, formulated also below, that criminalistics is, in essence, the mainly practical and - to a smaller extent-theoretical science of criminal investigation ${ }^{1}$, in other words, it is a branch of criminal sciences that explores, creates, systemizes and applies - within normative legal frames, means and methods for the detection (prevention) and proof of crime. Apart from the supplementary role of the effective-indirect and direct-prevention of crime, its basic functions comprise detection, obtaining as much and as reliable evidence as possible, providing a basis for and ensuring the ultimate establishment of

\footnotetext{
* Dr. univ. ec., Ph.D., Dr. habil. Associate Professor at University of Pécs, Faculty of Law, 7623 Pécs, Atléta u. 12. Research fields: Criminalistics, Criminal Procedure, Criminaltactics, and Lineup Method. ${ }^{1}$ It is to be noted, however, that (most of) the methodology (collection of recommendations) and system of means of criminalistics provide help not only in establishing the facts of criminal cases, but they may also be utilized by the appliers of other fields of law as well, including administrative law, infringement law, labour (eg. disciplinary) law and civil law. It is not by accident that János Zlinszky points out the fact that the Latin word "crimen" originally means "discriminating", in other words, it is used not exclusively in the criminal field, but it may be applied to the facts of any type of case. Zlinszky János: Római büntetőjog. (Roman criminal law) Tankönyvkiadó, Budapest, 1990. 11.
} 
criminal responsibility by the court. In summary, criminalistics is the science of the effective and professional investigation of crime, which has no subfield, either on the European continent having given birth to it or beyond the borders of Europe, that does not serve the fight against crime, the detection of offenders and their being brought to trial.

\section{DEFINITIONS OF CRIMINALISTICS IN EUROPE}

Definitions similar to the one given above have been formulated by academic literature before. Out of the (numerous) sources available, the author would like to highlight four definitions written by a famous German, American, Russian and Hungarian author respectively. According to the German Friedrich Geerds, "Criminalistics is the factual or empirical science of the doctrine of direct, repressive and preventive criminal investigation activities implemented in practice by criminal investigation organs and their helpers." ${ }^{2}$ In the American Paul Kirk's view, criminalistics is but the "Science of (individual) Identification", while Russian Belkin considers that criminalistics deals primarily with the collection, comparison, analysis and use of information and evidence connected with crimes and it also includes rules relating to detection, investigation and prevention.

The criminalistics is the science about regularities of the mechanism of a crime, occurrence of the information on a crime and its participants, about regularities of collection, collation, examination and using evidence, and also based on knowledge of these regularities means and methods of detection, investigation and prevention of crimes. ${ }^{4}$

According to Hungarian László Viski’s definition:

the science of criminal investigation deals with the elaboration of methods and means that promote the detection, prevention and interruption of criminal offences and the enforcement of criminal claims within the frames of statutory law. ${ }^{5}$

There is also a French idea that characterizes criminalistics as "l'art de

\footnotetext{
${ }^{2}$ F. Geerds, A kriminalisztika helye a tudományok rendszerében (The Role of Criminalistics in the System of Sciences) in A kriminalisztika aktuális kérdései (Katona Géza (szerk.), BM Kiadó, Budapest, 2001. 5).

${ }^{3}$ P. KIRK, CRime InVeStigation (Interscience Publications. New York-London-Sydney, 1953); C. Champod, Overview and Meaning of ID in ENCYClOPEDIA OF Forensic SCIENCES 1-2-3, (J. A. Siegel, P. J. Saukko, G. C. Knupfer, eds. Academic Press, San Diego-San Francisco-New York-BostonLondon-Sydney-Tokyo, 2000. Volume 3, 1077).

${ }^{4}$ R. S. Belkin, CRiminalistics EnCYCLOPEDIA (2nd edition, 2000); A. G. Filippov, The Russian Criminalistics - a Science and a Discipline in Bizonyítékok (EvIDENCE) (Cs. Fenyvesi, Cs. Herke, B. Mészáros eds., PTE ÁJK, Pécs, 2006. 154).

${ }^{5}$ LÁSZLó VISKI, Kriminalisztika (CRIMINALISTICS) (BM, Budapest, 1961. 13).
} 
la deduction", namely, the art of deduction. ${ }^{6}$ One cannot properly speak of art, but the reference to deduction may be considered appropriate, since causal thinking has a central role in criminalistics. It is the harmful-criminal result (criminal act) that appears before the criminalist, and he has all the right to be eager to find out the causal relations. He has to proceed backwards, from the result toward the cause, in other words, he has to go through a process of deduction in order to reveal and discover the past. (Criminal investigation activity is necessarily an activity characterized by a retrospective approach.)

Earlier criminalistics itself also used to be classified as art by some people. Their opinion is refuted by the other designations containing the expressions "scientific" and "forensic" also appearing in the title of one of their volumes. These days, characterized by a strong focus on science, this approach is no longer encountered in monographs on this subject. ${ }^{7}$

In connection with crime prevention being contained in the definition one may perceive some kind of shift (tendency) in world criminalistics from the reactive (retrospective) approach toward proactive, preventive measures. This has been particularly true since the US terrorist attacks of September 11,2001 , which have accelerated and intensified this process. It must also be noted here that, regarding the interpretation of the function of crime prevention, distinction is made between its indirect and direct form.

With regard to the indirect function, it is shown that the fundamental aim and task of criminal sciences is the promotion of the fight against crime, with a particular focus on the legal and non-legal means and methods of crime prevention. This characterizes, for example, criminal law, which places emphasis on individual and general prevention. As regards criminalistics, it is also possible and necessary to refer to the well-known scientific-empirical tenet (of Beccaria) that one of the most important components and most effective guarantees of the prevention (reduction) of crime is the detection of all crimes and offenders. It is so, because then the potential offender considers it too dangerous (risky) to commit a crime in the future. Consequently, (through this indirectly) criminalistics also fulfils a general crime prevention function by increasing and further developing the means and methods serving the detection and proof of crimes.

As an interpretation of the direct crime prevention function of criminalistics one may add that it has had rather varied forms, which change constantly even today and, therefore, one may undertake to provide only an

\footnotetext{
${ }^{6}$ L. Chauveau, Les traces du crime. Enquete sur la police scientifique (Calmann-Lévy, 1993. 24).

${ }^{7}$ For earlier works, see W. I. B. BEVERIDGE, THE ART OF SCIENTIFIC InVESTIGATION (Random House, New York, 1957); J. Fisher, The ART OF DeteCtion (Carlton Press, New York, 1963).
} 
exemplary list of them. They include general and crime-specific recommendations relating to conduct (behaviour), tactical suggestions about how to avoid becoming a victim, technical and organizational recommendations connected with the "protection of objects", promotion of the use and installation of means of security technology, including numerous alarm devices (light, noise, movement) forwarding a signal to the authorities, encouraging the use of traps offered by security technology (trace, object, chemical, general technical, picture-film-video). On the other hand, one may also classify under this category the tactics of timing criminal procedural coercive measures (and not only with a view to preventing finishing the perpetration of a prepared or attempted crime or the commission of further crimes), the execution of investigatory acts with a pedagogical aim, especially in the case of child offenders or juveniles.

Even the expression "criminalistics" is of European origin, since it was first used by Hans Gross (1847-1915), the founder of the discipline-also considered the "father" of criminalistics — in his basic work of $1893^{8}$, which was translated in the English language publication as the headword "criminal investigation"9 and it was used in that form right until the 1950s$1960 \mathrm{~s}^{10}$, and it is still used today, albeit with a changed content.

This is also a minor sign pointing in the direction of the fact that there were differences between the continental and common law jurisdictions also concerning criminalistics, which is based mainly on natural sciences, and to some extent, these differences exist even today.

In the title of the English language volume of 1950 (by J. M. A. Adam, and J. C. Adam, ) one may notice one more peculiarity, namely, that Gross is being referred to as the Professor of "Criminology", since at the time of the

\footnotetext{
${ }^{8}$ H. Gross, Handbuch für Untersuchungsrichter als System der Kriminalistik 1-2, Leuscher u. Lebensky's Buchhandlung, Graz, 1893.

${ }^{9}$ H. Gross, Criminal Investigation: A Practical Textbook for Magistrates, Police OfFicers AND LAWYERS. (J. C. Adam Trans., Sweet and Maxwell, London, 1924); (The Austrian Gross, the founder of the "doctrine of the realia of criminal law" worked as a professor in Graz, Prague and Chernivczi in the Ukraine). Based on Hans Gross, the expression "Criminal Investigation" was still used in a book published in 1950 in England, Canada and Australia as well; See J. M. A. Adam \& J. C. Adam, Criminal Investigation. A Practical Textbook for Magistrates, Police Officers and Lawyers. (Adapted from the System Der Kriminalistik of Dr. Hans Gross. Professor of Criminology in the University of Prague.), Sweet and Maxwell, London, The Carxwell Company, Toronto, The Law Book Company of Australia, Sydney, Melbourne, Brisbane, 1950.

${ }^{10}$ Even one of the most famous American (Californian) criminalists, Paul Kirk used the term "investigation" in his general work published in 1953 (and the later editions), only combined not with the attribute "criminal", but with the word "crime", which did not change its essence; P. KIRK, CRIME InVESTIGATION (Interscience Publications. New York-London-Sydney, 1953); P. KIRK, CRIME Investigation, Physical Evidence and Police Laboratory (Interscience Publishers Inc., New York, 1966); P. Kirk, CRime InVESTIGATION (2nd Chichester, Wiley, 1974).
} 
writing of the work Gross himself considered criminalistics to form part of criminology. It became an independent discipline only later. In the English usage of England one often encounters this terminology, however, it is not this term that has become the established Anglo-Saxon terminology for designating the given field of science. Criminalistics means only one section ("branch") of forensic sciences as opposed to the continental approach. ${ }^{11}$

\section{DEFINITIONS OF CRIMINALISTICS IN ANGLO-SAXON COUNTRIES}

In the common-law jurisdictions (Great-Britain, USA, Canada, Australia etc.) "criminalistics" as a scientific term relating to the whole branch of science has not become widespread, or it is not to be interpreted in its European meaning. According to Géza Katona's formulation of similar content: "In the United Kingdom 'criminalistics' as a scientific term relating to the whole branch of science has not become widespread. The term 'forensic science' was partly identified with continental crime-solving techniques. Sources of academic literature used the designation 'scientific' with the same content as 'forensic' (judicial, criminal). Knowledge applicable to the exploration and proof of criminal offences was not considered to form part of 'criminal sciences'. Right until recently, by the scientific analysis or investigation of crime English academic literature usually meant the application of natural scientific methods". ${ }^{12}$

Following the initial "criminal investigation" (or "crime investigation", sometimes "crime detection")—-through the designations "scientific investigation" 13 and "police science" ${ }^{14}$ (the term "scientific" appearing as a transitional form paving the way for "forensic") - especially from the $1960 \mathrm{~s}^{15}$ the applicable terminology has been "forensic

\footnotetext{
${ }^{11}$ I have also found (a 1981 edition of) a journal launched as early as 1966 with the title "Criminologist", which used to bear the title "Crime and Detection" earlier. Publisher: Forensic Publishing Co., England. This phenomenon has been encountered also in French literature, namely: G. Beroud, Précis de criminologie et de police tehnique (Paris, Payot, 1938); G. Picca, La criminologie. (5 éd.) (Presses Universitaires de France Paris, 2000).

${ }^{12}$ KATONA GÉZA, A kriminalisztika és a bűnügyi tudományok (THE CRIMINALISTICS AND THE CRIMINAL SCIENCES) (BM Kiadó, Budapest, 2002. 39).

${ }^{13}$ W. I. B. BEVERIDGE, THE ART OF SCIENTIFIC INVESTIGATION (Random House, New York, 1957); F. E. Inbau, A. A. Moenssens, L. R. Vitullo, Scientific Police Investigation (Chilton, New York, 1972); L. C. Nickolls, The SCIENTIFIC InVESTigation OF CRime (Butterworth, London, 1956); J. W. OsterbuRG, THE CRIME LABORATORY, CASE StUdies OF SCIENTIFIC INVESTIGATION (Indiana University Press, Bloomington, 1968).

${ }^{14}$ R. M. Perkins, ElEments of Police Science (The Foundation Press, Inc., Chicago, 1942).

${ }^{15}$ F. LUdQUist \& A.S. CuRRY, METHOdS OF ForEnSIC SCIENCE (Interscience Publishers, New York, 1962-1965); H. J. Walls, Forensic SCIENCE: AN INTRODUCTION TO THE SCIENCE OF CRIME DeteCtion (Praeger, New York, 1968).
} 
science"16 (or its plural form "forensic sciences"17, referring to its manifold character), criminal science (or court science, or maybe judicial science). In our view, there is no need to find a Hungarian translation for this term, since the attribute "forensic = forenzikus" can serve as a solution that may be accepted internationally as well. ${ }^{18}$ Therefore, in our opinion, the term "forenzikus tudomány" as the Hungarian expression for the common law terminology (forensic science) is simply a Hungarianized equivalent, its attributive form is adequately expressive and it is becoming more and more accepted.

On the other hand, in our view, today forensic science as a technical term of American origin based on the common law conception ${ }^{19}$, as a matter of fact, exhibits the content of continental crime-solving techniques, while the elements of crime-solving tactics can mainly be detected in criminal psychology (or forensic psychology) and "criminal investigation". Consequently, by scientific investigation of crime ("forensic/scientific investigation") or detection of crime ("detection") ${ }^{20}$, Anglo-Saxon academic literature means the application of natural scientific methods. Based on the traditional approach, behind "criminalistics" as a technical term there is only one "branch of forensic science", namely the one that deals specifically with the scientific collection and analysis of physical evidence, especially of traces and material remains found during the inspection of the crime scene (crime scene investigation, reconstruction) concerning a specific crime

\footnotetext{
${ }^{16}$ The origin of the word "forensic" may be traced back to the Latin word "forum" forming the basis of "forensis". This was a place (institution) in Ancient Rome where important matters of life could and had to be debated in public (within the competence of the forum, before the forum) and it was the place where justice was administered. As for the present approach, one might add, important questions of fact (relating to crime), constituting at the same time questions of life and death, because the effects and criminal law consequences of the individual pieces of evidence may and do have a serious impact on the life and fate of the (guilty) person concerned (and his family).

${ }^{17}$ Pursuant to Pete Moore's definition of forensics: "The term 'forensic' means suitable for a court of law. In all cases, forensic science demands diligence and attention to detail if the work is going to bridge the gap from the crime scene to the courtroom. ... Forensic science should lead investigators to the truth." P. Moore, The Forensics Handbook. The Secrets of Crime Scene InVestigation (Barnes and Noble Books, New York, 2004. 6).

${ }^{18}$ With regard to "forensic science(s)", this position is held also by Gabriella Kármán. "It is translated as bünügyi tudományok = criminal sciences, igazságügyi tudományok = judicial sciences, but in my opinion these terms do not express the required content. Therefore, I will continue to use the term "forenzikus tudományok = forensic sciences", which is increasingly applied in Hungarian academic literature.” Gabriella Kármán, A krimináltechnika és az igazságügyi szakértői diszciplínák fejlődéstörténetének legújabb kori eseményei. (The Newest Events of Criminaltechnic and Expert Disciplines.) Kriminológiai tanulmányok. 49, Országos Kriminológiai Intézet, Budapest, 2012. 70.

${ }^{19}$ The term "scientific investigation" is also used in English academic literature. On this, see L. C. NiCKOLLS, THE SCIENTIFIC INVESTIGATION OF CRIME (Butterworth, London, 1956).

${ }^{20}$ For the use of "detection", see C. R. M. CuthBERT, SCIENCE AND THE DETECTION OF CRIME (Hutchinson Scientific and Technical, London, 1938).
} 
committed.

According to Géza Katona's formulation" ${ }^{21}$ : "In the United States the term 'forensic sciences' means scientific knowledge applied to the exploration, analysis and assessment of physical evidence. Its main branches are criminalistics and forensic medicine." It is to be added that "a characteristic feature of the US legal system is that it does not draw a sharp line between proof by expert evidence in criminal procedure and that in civil procedure. The Federal Rules of Evidence apply to both fields and provide guidance as to the subject-matter and method of the expert statement. For this reason the 'Federal Judicial Center' as a government organ issues thematic textbooks in order to provide judges and court employees with information and improve their professional knowledge."22

In recent decades, however, a tendency of some kind of approximation, interplay, unification of content and convergence (even if not with identical forms of expression) has been observable concerning the two conceptions: the continental and common law approaches. ${ }^{23}$ Since the 1960s there have been and still are an increasing number of volumes published under the title "Criminalistics", drawing nearer to the continental designation. One example for this is the Lab Manual volume published in the United States in 2001. Its sub-title ("An introduction to forensic science") refers to forensic science, at the same time the main title is "Criminalistics" 24 . As for its content, it provides a detailed analysis of the meticulous methodology relating to the examination of physical evidence based on natural scientific knowledge. A similar conception may be found in the works of several authors, let us mention as an example the case of O'Hara. In two of his basic works, he deals with "Criminalistics" (having the nature of crime-solving

\footnotetext{
${ }^{21}$ Katona Géza, A kriminalisztika és a bünügyi tudományok (THE CRIMINALISTICS AND THE CRIMINAL SCIENCES) (BM Kiadó, Budapest, 2002. 40).

${ }^{22}$ A similar interpretation is represented by József Molnár in his essays published in parts; J. Molnár, A kriminalisztika tudománya I-V (The Science of Criminalistics) Kriminológiai és Kriminalisztikai Tanulmányok (The Science of Criminalistics I-V. Studies on Criminology and Criminalistics), OKRI, Budapest, 1995-1999.

${ }^{23}$ One may also formulate it in such a way that the European continental approach proceeds towards forensics and the Anglo-Saxon approach is getting closer to the criminalistics approach. The former process may be considered stronger because of the world tendency, the priority of crime-solving techniques and the shifting of focus to natural scientific analyses. For more on this, see Fenyvesi Csaba, A XXI. századi bünüldözés-tudomány nemzetközi tendenciái (21 Century International Tendencies of Criminal Investigaton) 757-765 (Magyar Tudomány, 2004/6).

${ }^{24}$ C. E. Meloan, R. E. James, R. SAFERStein, CRiminalistics, An Introduction to Forensic Science. (Lab Manual, Prentice Hall, Upper Saddle River, New Jersey, 2001). From earlier, see P. O. Kevin \& R. C. Sulliban, CRIMINAlistiCS, Theory and Practice (Holdbruce Science Publishers Inc., New York, 1976); R. SAFerstein, Criminalistics, An Introduction to Forensic Science (Englewood Cliffs, N.Y. Pearson, Prentince Hall, New Jersey, 1995, 2004); O’Brien K. P. \& Sullivan R. C., CRiminalistics, Theory and Practice (Holbrook Press, London, 1976).
} 
techniques) and "Criminal investigation" (having the nature of crimesolving tactics). ${ }^{25}$ In the 2000 s, especially in American general works one may-repeatedly-increasingly encounter the expression "criminal investigation" 26 , which is also drawing nearer to the continental use of terminology. As for its content, nowadays it covers mainly continental crime-solving tactics and crime-solving methodology. More specifically, it comprises methods of crime scene investigation, line-up or one on one confrontation (USA), or identity parade (England), the interrogation (USA) or questioning (England) of suspects and witness interviews. This category also includes data collection from informants, analyses and other sources (e.g. records, surveillance), latent investigation ${ }^{27}$, the planning, organization, logistics and "management" 28 of investigation, modes of search, bodysearch, seizure, the tactics of arrest, custody, detention, pre-charge detention, preliminary detention, the interpretation of rules of evidence, as well as tactical recommendations, professional "tricks of the trade" applicable to the individual crimes and groups of crime ${ }^{29}$. Thus, on the whole, the review of content elements leads us to the conclusion that, basically, both approaches divide the field of science designated as criminalistics by us and on the Continent into identical areas. In other words, criminalistics is divided into crime-solving techniques, constituting the forensic part- "forensic science" or "sciences" in the plural with reference to the underlying natural

\footnotetext{
${ }^{25}$ C. O’Hara \& J. W. Osterburg, An InTRoduction to Criminalistics (New York, 1960); C. O'HARA, G. O'HARA, Fundamentals of CRiminal InVESTIGATION (6th edition, Springfield, 1994).

${ }^{26}$ C. R. Swanson, N. C. Chamelin, L. Territo, Criminal Investigation (McGraw-Hill, Boston, 2002); P. B. Weston \& C. Lushbaugh, Criminal Investigation-Basic Perspectives (Prentice Hall, Upper Saddle River, 2003).

${ }^{27}$ The aptly applied term "latent investigation" ("invisible" or more simply "latent") includes some elements of crime-solving tactics according to the volume "Criminal Investigation" of 1981. The volume describes - with regard to particularly serious crimes - the importance of data obtained from crime analysis, internal and external informants and registers (National Crime Information Center) and (hidden, covert, disguised) surveillance and mechanical lie detection, as well as from victims and witnesses; C. R. Swanson, N. C. Chamelin, L. Territo, Criminal Investigation (McGraw-Hill, Boston, 1981); and Bence Mészáros, A fedett nyomozás a bünüldözésben. (Covered investigation.) PhD-thesis, Pécs, 2011.

${ }^{28}$ P. B. Bloch \& D. R. Weidman, Managing Criminal Investigations (U.S. Government Printing Office, Washington, D.C., 1975); W. J. OSTERBURG \& H. R. WARD, CRIMINAL INVESTigATION: A Method For ReCOnSTRUCTING THE PAST 271-279 (6th ed. LexisNexis, Anderson Publishing, New Providence, NJ, 2010).

${ }^{29}$ Among the methodological groups classified in works, the first place is always taken by homicidemurder-manslaughter, assault and battery, followed in order by robbery-kidnapping, burglary, arson, crimes involving explosives, rape and other sex crimes, crimes against property (larceny-theft, fraud, cheating, embezzlement etc.), terrorism, computer and technological crime, enterprise-organisedeconomic-white-collar crime, traffic crimes (road accidents), forgery and counterfeiting, bribery, drug-abuse and other less frequently committed crimes. (As examples for the latter type, let us mention: school violence, ritual crimes, identity theft, etc.).
} 
sciences - and crime-solving tactics based mainly on social scientific knowledge, which is embedded in "criminal investigation" and "criminal psychology" in common law academic literature. Crime-solving methodology focussing on individual crimes is also included in "criminal investigation".

\section{COMPARING OF THE TwO SYSTEMS OF CRIMINALISTICS}

In addition to the above, it must be noted that out of the continental countries, in France (Belgium ${ }^{30}$, Italy ${ }^{31}$ ) apart from criminalistics ("la criminalistique" $)^{32}$, or the knowledge termed as "police scientifique" ${ }^{33}$ or scientific police ${ }^{34}$, judicial police science ("police judiciaire") ${ }^{35}$ or, pursuant to Locard's "Manuel de technique policiere", police technique ${ }^{36}$ has also been linked to the cultivation of some areas of criminal investigation. However, parallel to the above, the term "criminalistics" has also appeared by today. ${ }^{37}$ The university textbook published in Paris in 2001 already bore the main title "Manuel de criminalistique modern" (Manual of modern criminalistics) and the sub-title "La science et la recherce de la prevue" (The

\footnotetext{
${ }^{30}$ See E. Goddefroy, Manuel elémentaire de police technique. Ferdinand Larcier, Bruxelles, 1922; E. Goddefroy, Manuel de police technque, Ferdinand Larcier, Bruxelles, 1931; R. Lechat, La technique de L'enquete criminelle. Ed. Moderna, Bruxelles, 1959; F. E. Louwage, Technique et tactique de la police criminelle. Ninove, Belgique, 1948.

${ }^{31}$ In Italy the use of terminology follows the French pattern, in other words, "scientific police" and "police techniques" are the most frequently used terms; S. OtTolEnghi, Polizia ScIENTIFICA (Societa Editrice Libraria, Roma, 1910); E. Altavilla, Psicologia Giudiziaria (Utet, Napoli, 1932); E. Altavilla, Psicologia Giudiziaria (Torino, 1955).

${ }^{32}$ Ceccaldi P. F., La criminalistique. "Que sais-je?" Presses Universitaries de France, Paris, 1962; G. Chevet, Ph. Marand, Cours de criminalistique. Préfecture de police, Paris, 1981; A. Buquet, Manuel de criminalistique moderne. (La science et la recherche de la preuve), Presses Universitaires de France, Paris, 2001.

${ }^{33}$ Presumably under the influence of Mediterranean European countries, a general work on criminalistics was published under the title "Polícia científica" in Brazil. L. Ribeiro, Policia Scientifica. Editora Guanabara, Rio de Janeiro, 1934.; In France: M. Bischoff, La police scientifique. Payot, Paris, 1938; Ch. Diaz, La police technique. Presses Universitaires de France, Paris, 2000.

${ }^{34}$ H. M. Robinson, La science contre la crime. Payot, Paris, 1941; Ch. Sannie, La recherche scientifique du criminel. Armand Colin, Paris, 1954.; J. Gayet, Manuel de police scientifique. Payot, Paris, 1961, 1965, 1968; J. Gayet, ABC de police scientifique. Ed. Payot, Paris, 1973.

${ }^{35}$ V. Hreblay, La police judiciaire. Presses Universitaries de France, Paris, 1997.

${ }^{36}$ E. Locard, L'enquéte criminelle et les méthodes scientifiques. Flammarion, Paris, 1920; E. Locard, Manuel de technique policiére. Payot, Paris, 1923, 1948. E. Locard, Traité de criminalistique. 1-6. Vol. Desvigne, Lyon, 1931-1940. It is obvious from the list that Locard used almost all forms of the French designations. Out of them, he chose "criminalistics" as the title for his six-volume general work (following Gross). Further authors and their works: J. Gayet, Manuel de police scientifique. Payot, Paris, 1961; M. Le Clere, Manuel de police technique. Ed. Police Revue, Paris, 1974. ${ }^{37}$ See E. Locard, Traité de criminalistique. 1-6. Vol. Desvigne, Lyon, 1931-1940; P. F. Ceccaldi, La riminalistique. Presses Universitaires de France, Paris, 1962; G. Chevet, Ph. Marand, Cours de criminalistique. Préfecture de police, Paris, 1981; J. Fombonne, La criminalistique. Paris, 1996.
} 
science and research of evidence) ${ }^{38} 39$.

In Europe in German-speaking countries and to the east of them, the term "criminalistics" was customary almost everywhere and this is the accepted terminology today as well. ${ }^{40}$

At the same time, one may also observe changes in the continental conception, more specifically, phenomena, the adoption ${ }^{41}$ and application of terms pointing in the direction of forensics. It is being infiltrated through the cultivation and terminology of the subfields applied in the common law system. As an example of approximation and convergence between the two systems one may mention that the interpretation of evidence (the "show up" model $)^{42}$ plays an increasing role in the continental approach as well.

It may also be perceived concerning both schools of thought that the

\footnotetext{
${ }^{38}$ A. Buquet, Manuel de criminalistique moderne (La science et la recherche de la preuve), Presses Universitaires de France, Paris, 2001.

${ }^{39}$ The title also refers to the important fact that there is a strong connection between evidence and criminalistics, and this connection applies - in my view - not merely to evidence in criminal procedure, but also to evidence in branches of law and fields of application of law where there is demonstration of evidence. (For example, in administrative, labour law and civil law cases, as it has already been pointed out above). Therefore, criminalistics is a science of facts which is not merely a "police science" intended to serve the members of the main investigation authorities and policemen, but due to its methodology, it is a field of science playing a role in all branches of law dealing with evidence and thus - in my view — it has and must have a place and role in the training of law students, future legislators and appliers of law, and also in the curricula of the individual law faculties. For an earlier detailed discussion of this idea by the author, see Fenyvesi Csaba, A kriminalisztika mint tudományág és mint egyetemi tantárgy (The Criminalistics as a Scientific Branch and University Subject) 196-201 (Magyar Tudomány, 2003/2); And Flórián Tremmel, Bizonyítékok a büntetőeljárásban. (Evidence in Criminal Procedure), Dialóg Campus Kiadó, Budapest-Pécs, 2006. ${ }^{40}$ This designation also appears in lexicons and encyclopaedias, including H. Gross, Encyklopädie der Kriminalistik. Verlag von F. C. W. Vogel in Leipzig, 1901; I. Anghelescu, M. Constantinescu, In colectiv, Dictionar de criminalistica. Editura Stiintifica si Enciclopedica, Bucuresti, 1984, 1996; R. S. BELKIN, CRIMINAlistics ENCYClOPEDIA (2nd edition, 2000); W. Burghard, H. W. Hamacher, H. Herold, M. Schreiber, A. Stümper, A. Vorbeck, Kriminalistik Lexikon. Kriminalistik Verlag, Heidelberg, 1986; D. Modly, Pirucni kriminalisticki leksikon. Sarajevo, 1998. Bócz Endre (ed.): Kriminalisztika I-II. BM Duna Kiadó, 2004; In the US a similar encyclopaedia was published under the title "forensic" already; See J. Siegel, P. J. Saukko, G. C. Knupfer (eds.), Encyclopedia of Forensic Sciences. Volume 1-3. Academic Press, San Diego-San Francisco-New York-Boston-LondonSydney-Tokyo, 2000.

${ }^{41}$ For example, in German academic literature the Anglo-Saxon attribute "forensic" appeared already several decades ago (following the American term launched in the 1960s); See H. Liebel, W. Uslar, Forensische Psyhologie. Kohlhammer, Stuttgart, 1975; For an example from today, see C. Dern, Die Zukunft forensischen Wissenschaften 292-297 (Kriminalistik, 2009/5).

${ }^{42}$ The expression indicates that in accordance with the common law approach the test of the investigation is whether the revealed evidence and the relating opinion can stand the test of trial, whether the prosecutor can demonstrate to the required extent - with the help of detectives and experts (expert witnesses) - his scientifically well-founded evidence, whether he can convince-by the obtained physical evidence - the court and lay jurors, for whom the continuously developing modes of crime-solving techniques (second generation evidence and the paths leading to them) are becoming more and more complicated.
} 
underlying basic scientific knowledge is derived from (forensic) biology, chemistry, physics, anthropology, pathology, serology, toxicology, but there are also close links with applied ballistics ${ }^{43}$ and photographic technology (visual record photograps). In recent decades this circle has been extended to cover, as new fields, molecular genetics, information technology (computer forensic technology, cyber forensics, digital forensics, digital investigation, web-analysis), including for example the computerized analysis of human voice and voice carriers (computer-voice analysis), identification of computer writing and computer printers (printeridentification), forensic archaeology, forensic dentistry, modern forensic entomology dealing with insects, modern ${ }^{44}$ forensic geology, DNA profiling (DNA analysis), forensic botany and zoology.

As a special technical method one may also mention the analysis of evidence (crime analysis) - operating with the help of crime mapping and geographic profiling ${ }^{45}$, the application of the mathematics-based Bayes' Theorem ${ }^{46}$ in the context of identification analyses, the theory of document analysis (hand- and machine-written documents), images analysis, and analyses for the identification of ridges and edges in skin patterns ("ridgeology"-“edgeology").

Within the range of tactics, one may highlight knowledge of forensic administration-management and logistics, forensic nursing, security management and personality profiling (profile-analysis). As new-a few decades old or even younger-fields in the methodology of individual crimes one may regard, for example, the investigation of accidents caused by design or construction (engineering failures), cases of fire (fire science)

\footnotetext{
${ }^{43}$ See Hautzinger Zoltán, A kriminalisztika ballisztika. (Forensic Ballistics) in Fenyvesi Csaba-Herke Csongor (szerk.): Minúciák. Tanulmányok Tremmel Flórián professzor 60. születésnapjának tiszteletére 161-171 (PTE ÁJK, Pécs, 2001).

${ }^{44}$ The word "modern" has been added, because Hans Gross also dealt with earth as material remains as early as the 19th century. He mentioned its significance from the aspects of criminalistics and identification already in his catalogued basic work of 1893. Based on his practical experience he mentioned that the analysis of material remains found on the shoes of the suspect could help in revealing the route taken by the perpetrator. As he formulated: "Mud found on shoes may reveal more about the last place visited by the person wearing those shoes than a tiring questioning" (translation by the author).

${ }^{45}$ The essence of Geographic Profiling lies in the fact that based on the connected scenes some computer software determines the most likely place of residence of the attacker. Geographic profiling is a subtype of profiling; therefore it is also connected with psychological and behavioural profiling, which rather forms part of crime-solving tactics. The reason for classifying geographic profiling as belonging to the field of criminal techniques is that psychological profiling seeks to answer the question "who", while geographic profiling attempts to give a reply to the question "where". ${ }^{46}$ See József Orbán, A jog konvergenciája a természettudományok felé a Bayes analízis apropóján (On Ground of Bayes-Analysis the Convergence of Law toward Natural Sciences) 42-46 (Glossa Iuridica, 2012/1).
} 
and explosions (bombs, explosives and residues).

\section{CONCLUSION}

In summary, it may be concluded that although there are notional differences between the continental and common law conceptions of the science of criminal investigation (criminalistics and forensic sciences), their subject-matter and objectives are identical, and their contents are in accord with each other. As a tendency it may be established that one may witness the gradual demolition of the rigid boundaries between these conceptions, and the present is already characterized by their mutual interaction. 